\title{
Preservative spleen surgery and hyperbaric oxygen therapy ${ }^{1}$
}

\author{
Cirurgia conservadora do baço e oxigenoterapia hiperbárica
}

\author{
Isabel Cristina Andreatta Lemos Paulo ${ }^{2}$, Danilo Nagib Salomão Paulo ${ }^{3}$, Luiz Cálice Cintra ${ }^{4}$, Maria Carmem Silva \\ Santos $^{5}$, Hildegardo Rodrigues ${ }^{6}$, Thiago Antunes Ferrari ${ }^{7}$, Tiago Caetano V. de Azevedo ${ }^{8}$, Alcino Lázaro da Silva ${ }^{9}$ \\ 1. Study performed at the Laboratory of the Division of Surgical Principles, Department of Surgery, School of Science, Santa Casa de \\ Misericórdia, Vitória - ES(EMESCAM)-Brazil. \\ 2. Assistant Professor of Surgery, EMESCAM. MS, Fellow PhD degree of Surgery , School of Medicine, Federal University of Minas Gerais, Brazil. \\ 3. Full Professor of Surgery, EMESCAM, Brazil. \\ 4. Associate Professor of Pathology, School of Science, Santa Casa de Misericórdia, Vitória - ES(EMESCAM)-Brazil. \\ 5. Associate Professor of Pathology, Federal University of Espirito Santo, Brazil. \\ 6. Full Professor of Anatomy, School of Science, Santa Casa de Misericórdia, Vitória - ES(EMESCAM)-Brazil. \\ 7. Graduate student of School of Science, Santa Casa de Misericórdia, Vitória - ES(EMESCAM)-Brazil. \\ 8. Graduate student of School of Science, Santa Casa de Misericórdia, Vitória - ES(EMESCAM)-Brazil. \\ 9. Full Professor of Digestive System Surgery, School of Medicine, Federal University of Minas Gerais, Brazil.
}

\section{ABSTRACT}

Purpose : To assess functional and morphological aspects of spleen auto-implants and of the splenic inferior pole of rats, post-operatively treated or not with hyperbaric oxygen, as well as the survival of these animals, were studied. Methods: Seventy-eight male Wistar rats, weighing between 192 and 283 g ( 238,3 \pm 9,6g), were randomly distributed into three groups: Group1-(n=20), spleen manipulation; group 2-(n=36), spleen auto-implantation; group3-(n= 22), subtotal splenectomy preserving the inferior pole. Each group was subdivided as follows: subgroup a, not submitted to hyperbaric oxygen therapy: $1 a(n=10), 2 a(n=21), 3 a(n=13)$; subgroup $b$, submitted to the therapy: $1 b(n=10), 2 b(n=15), 3 b(n=9)$. Blood was collected pre-operatively and 11 days after surgery, for the estimation of lipids and immunoglobulins and the counting of platelets and Howell-Jolly corpuscles. The spleen and remains were taken for histological study. Results : The number of surviving animals was significantly higher in groups $1(\mathrm{p}<0,01)$ and $3(\mathrm{p}<0,05)$ relative to those of subgroup 2a. Total cholesterol and the LDL fraction increased significantly in subgroup $2 \mathrm{a}(\mathrm{p}<0,01)$ and $3 \mathrm{a}(\mathrm{p}<0,05)$, and remained unaltered in subgroups $2 b$ e $3 b$. IgM decreased more significantly in subgroup 2 than in subgroup 3 ( $p<0,001$ vs $p<0,01$ ). The increase of platelet numbers and the appearance of Howell Jolly corpuscles was smaller in subgroup 2b compared to subgroup $2 \mathrm{a}$, and in group 3 compared to group aqui- $>2$. The macro and microscopic appearance in subgroup $2 \mathrm{~b}$ were more viable than in subgroup 2a, and that of group 3 more viable than in group 2. The survival of the animals carrying their whole spleen or its inferior pole was more frequent than that of the auto-implanted animals. Conclusion : Functionality and viability of the whole spleen or of its inferior pole, were better than in the auto-implanted animals. Hyperbaric oxygentherapy contributed to increased survival frequency of auto -implanted animals, and to improve the functionality and viability of the auto-implants and the function of the inferior splenic pole, and did not interfere in animals carrying their whole spleen. Key words: Splenectomy/methods.Spleen/metabolism. Adverse effects/splenectomy. Oxygen inhalation therapy/methods

\section{RESUMO}

Objetivo : Estudar aspectos funcionais e morfológicos dos auto-implantes esplênicos e do pólo inferior do baço de ratos, tratados ou não com oxigênio hiperbárico no pós-operatório, e a sobrevida desses animais. Métodos: Foram operados 78 ratos, machos, Wistar, pesando entre 192 g e 283 g ( M.A238,3 + 9,6), distribuídos aleatoriamente em três grupos : 1- (n=20) , manipulação do baço; 2- (n=36), auto-implante esplênico; 3(n=22), esplenectomia subtotal com preservação do pólo inferior. Cada grupo foi dividido em dois subgrupos: a- não submetido à oxigenoterapia hiperbárica: 1a(n=10), 2a(n=21), $3 a(n=13)$; b- submetido: $1 b(n=10), 2 b(n=15), 3 b(n=9)$. O sangue foi colhido para dosagem dos lípides e imunoglobulinas e contagem das plaquetas e dos corpúsculos de Howell-Jolly no pré-operatório e 11 dias após a cirurgia. O baço e os remanescentes foram retirados para estudo histológico. Resultados : O número de animais sobreviventes foi significantemente maior nos grupos $1(p<0,01)$ e $3(p<0,05)$ em relação ao subgrupo 2a. O colesterol total e a fração LDL aumentaram significantemente nos subgrupos $2 a(p<0,01)$ e $3 a(p<0,05)$, e não alteraram nos subgrupos $2 b$ e $3 b$. A IgM caiu mais significantemente no grupo 2 que no 3. O aumento do número de plaquetas e o aparecimento dos corpúsculos de Howell Jolly foi menor no subgrupo $2 b$ que no 2a, no grupo 3 que no grupo 2. O aspecto macro e microscópico no 
subgrupo 2 b foi mais viável que no subgrupo 2a, e o do grupo 3 mais viável que no grupo 2. A sobrevida dos animais com todo o baço ou com o pólo inferior foi mais freqüente que a dos animais com auto-implantes. Conclusões : A função e a viabilidade de todo o baço ou do pólo inferior foram melhores que a dos auto-implantes. A oxigenoterapia hiperbárica contribuiu para aumentar a freqüência de sobrevida dos animais com auto-implantes, para melhorar a função e a viabilidade dos auto-implantes e a função do pólo inferior, e não interferiu nos animais com baço íntegro.

Descritores: Esplenectomia/métodos. Baço/metabolismo. Efeitos adversos/esplenectomia. Terapia de inalação de oxigenio/métodos.

\section{Introduction}

Total splenectomy may evoke immediate and late complications. ${ }^{1}$ Among these, the most worrisome is fulminant sepsis, reported in 1952 by King e Shumacker Jr, 2 in 5 children submitted to total splenectomy for spherocytosis. Complicating infections following spleen removal, have also been observed in experimental animals.

${ }^{3,4}$ Besides these, alterations in lipid metabolism following splenectomy have been reported in human subjects ${ }^{5}$ and experimental animals ${ }^{6,7,8}$, capable of causing atherosclerosis.

${ }^{6}$ For these reasons, conservative spleen operations including vascular occlusions ${ }^{9,10}$, splenorrhaphies ${ }^{11}$, partial splenectomies 12,13,14 and auto-implants. ${ }^{15,16}$ have been valorized. Spleen auto-implants are the most controversials from a functional point of view, including the partial fulfillment of spleen function in lipid metabolism. ${ }^{17}$ In mice, such grafts present centripetal revascularization after the third day following operation. ${ }^{18}$ The most efficient function of these grafts however occurs after the 16th week. ${ }^{19}$ Subtotal splenectomy with the preservation of the organ's inferior pole (STPI), has been described in dogs ${ }^{7}$ and in rats. ${ }^{20}$ Such animals presented significant alterations of their cholesterol and LDL fraction in the mediate postoperation period. ${ }^{7}$ For these reasons, it appeared of interest to describe a resource that could contribute to the improvement of the functioning of spleen implants and of the inferior pole, so that their remnants could fulfill the spleen's important functions. ${ }^{21}$ Complications including death due to asplenia may thus be avoided. Considering that hyperbaric oxygentherapy (HBO) has an angiogenic effect ${ }^{22,23}$, stimulates collateral circulation ${ }^{24}$, has a beneficial effect in acute pancreatitis ${ }^{25,26,27}$, acts against various bacteria ${ }^{28,29,30}$, increases hepatic regeneration ${ }^{31}$, decreases obit and the deleterious effects on liver and spleen in rats submitted to hepatic veins ligature, ${ }^{32}$ we raised the hypothesis that this method might increase the viability and the functioning of auto-implants and of the spleen's inferior pole, as well as to possibly extend rats survival. We therefore performed this research work, aiming at the study of functional and morphological aspects of spleen autoimplants and of the spleen's inferior pole, in rats postoperatively exposed or not, to hyperbaric oxygentherapy (HBO), as well as to observe the clinical evolution of these animals.

\section{Methods}

This study followed the recommendations of COBEA (Brazilian College for Animal Experimentation), and was approved by the Ethics Research Committee of the Federal University of Minas Gerais, Brazil, according to ETIC document no100/2006. Seventy-eight male Wistar rats weighing between 192 and 283 g (mean weight $238 \mathrm{~g} \pm 9,6 \mathrm{~g}$ ), were provided by the animal house of the Escola Superior de Ciências da Santa Casa de Misericórdia de Vitória-ES, Brazil. The animals were distributed at random into three groups, as follows: Group1- $(n=20)$, spleen manipulation only; group 2-( $n=36)$, spleen autoimplantation; group3-(n=22), subtotal splenectomy with preservation of the organ's inferior pole. Each group was subdivided as follows: subgroup a, not submitted to hyperbaric oxygen therapy: $1 \mathrm{a}(\mathrm{n}=10), 2 \mathrm{a}(\mathrm{n}=21), 3 \mathrm{a}(\mathrm{n}=13)$; subgroup $b$, submitted to this therapy: $1 b(n=10)$, $2 b(n=15), 3 b(n=9)$ in the postoperative. Following a 12 hour fast, rats were submitted to analgesia evoked by $25 \mathrm{mg} / \mathrm{Kg}$ Ketamine hydrochloride injected into the muscle of the posterior paw, weighed (electronic Filizola ${ }^{\circledR}$ scale, 1 g sensitivity) and submitted to cardiac transthoracic punction for the collection of $1,2 \mathrm{~mL}$ of blood. Each animal was identified by an earmark and returned to its original cage. The collected blood was divided and placed either in a flask with EDTA for red blood cell, platelet and leucocyte count using an automatized Abott's Cell-Dyn $3700^{\circledR}$. (Illinois-USA), or in another flask without anticoagulant, for the estimation of immunoglobulins or lipids. Immunoglobulins were determined turbidimetrically using Behring's ${ }^{\circledR}$ Turbitimer( Marburg-Alemanha); lipids were measured in the Dimension AR DADE BEHRING ${ }^{\circledR}$ (Illinois, USA). Howell Jolly corpuscles were analyzed in 10 fields of blood spreads, under an Olympus ${ }^{\circledR}$ DX40 microscope . Rats were anesthetized by the intraperitonial route, with a mixture of Ketamine hydrochloride $(50 \mathrm{mg} / \mathrm{kg}$ ) and xylasine hydrochloride (3 mg/Kg ). Following anti-sepsis of the abdominal wall with topical Polvidine, $2 \mathrm{~cm}$ long midline laparotomy and abdominal cavity examination were performed. The spleen was manipulated in animals of group 1; in animals group 2, auto implantation of the spleen was performed in the following sequence: the stomach was pulled out of the abdominal cavity, exposing the spleen. Three ligatures with mononylon 4.0, adherent 
to the spleen, permitted the sectioning of the splenic vessels and the withdrawal of the organ. The spleen was divided in two parts, and each was weighed; one was placed in $4 \%$ formol for histology study, and the other cut into four parts, each of which was sutured to the omentum by a single simple 5.0 polypropylene tie, and covered with this peritoneal fold. Animals of group 3 were subtotally splenectomized with preservation of the inferior pole (STPI) as previously described. ${ }^{14}$. The abdominal wall was sutured in two planes: in the first, of the peritoneum and the muscle aponeurosis, and in the second, of the skin, using mononylon 4.0, with single simple basting. The following protocol was employed for hyperbaric oxygentherapy (HBO) of subgroup b; step A: immediately following recovery from anesthesia, rats were placed in the hyperbaric chamber (Figure 1), where oxygen pressure was progressively adjusted during 15 minutes to up to 2,5 atmospheres; step B: animals were exposed to this therapy for 90 minutes; step C: depressurization was applied for 15 minutes. Two daily sessions of $\mathrm{HBO}$ were given on the three first days; on the following seven days, only one daily session was applied. After withdrawal from the chamber, the animals were returned to their cages to receive water and food ad libitum and $200 \mathrm{mg} / \mathrm{Kg}$ paracetamol orally, dissolved in their drinking water. Animals that had died, were necropsized; survivors were killed on the eleventh day following the operation, using lethal doses of sodium pentobarbital, injected into the abdominal cavity, following a renewed blood collection for the repetition of the laboratory exams. The rats were weighed, and submitted to a U-shaped incision to expose and examine the abdominal viscera. The spleen of animals of group 1 , of the auto-implanted ones (group 2), and the inferior pole of those of group 3, were removed, examined, and weighed to 0.001g precision on an Adventurer OHAUS, model AR 3130 balance ( São Paulo-Brasil ), photographed and placed in 10\% formol. They were then included in paraffin blocks and cut to 3 micrometer thickness, extended on glass slides and dried for $24 \mathrm{~h}$ at $58^{\circ} \mathrm{C}$. Adhered to the slides, they were deparafinized in xylol and dyed with hematoxylin-eosin (H\&E) and Masson trichromate. Two pathologists performed microscopy, under a binocular microscope for morphological alteration analysis. Statistical analyses utilized were as follows: A-linear regression analysis to calculate the mean percentage of the inferior pole's mass in group 3, performed by dividing each pole's weight by the spleen's ideal weight for each animal of the simulation group, and multiplying the result by 100 . The ideal weight of the spleen was calculated utilizing the formula: spleen weight $=1,80 \mathrm{x}$ body weight $+230,49$. The mean of the remaining spleen mass plus its respective standard deviation was obtained. B-Anova for corresponding samples, to compare pre-operation weights with postoperation ones within the same group of animals, and the Kruskal Wallis test, to compare the weights between the three groups of animals. C-Student's t test to compare values of samples, for cholesterol and fractions, triglycerides, immunoglobulins and platelets obtained pre-operatively, with those obtained in the mediate (11 ${ }^{\text {th }}$ P.O) period. D- The chi-square test to compare the number of survivors and the frequency of Howell Jolly corpuscles existing between groups. Fisher's exact test was utilized when one of the expected frequencies fell below 5 . Differences were considered significant when $\mathrm{p}<0,05$ (5\%).

\section{Results}

The abdominal cavity of group 1 (simulation) animals, presented few and loose adherences to the spleen. In group 2 (auto-implants) marked adherences between the implants and the intestinal loops were observed. Adherences were less intense in group 3 (STPI), than in the implanted group. The inferior pole was sometimes adhered to the contiguous abdominal viscera (stomach, small intestine) and sometimes to the abdominal wall. No statistically significant differences between the weights of the three groups of the animals in the pre-operative stage were noted ( $p>0,05)$. Weight decrease was observed post-operatively in each group, independently of hyperbaric oxygen (HBO) treatment. This decrease was significant in rats submitted to auto-implantation $(\mathrm{p}<0,001)$ and to STPI $(p<0,05)$, and treated with hyperbaric oxygen. The mean weight of the spleens of group 2, was $907,66 \mathrm{mg} \pm 234,43$. The global mean weight of the auto-implants was $446 \mathrm{mg} \pm 115$, representing approximately $49 \%$ of the spleen. The mean mass percentage of the inferior pole was of $38,87 \% \pm 6,05 \%$, calculated by linear regression analysis. The number of surviving rats (Table 1), shows that in the simulation group, $100 \%$ of the rats survived, regardless of whether they had been treated or not by HBO. In subgroup $2 \mathrm{a}$, the survival frequency was significantly lower than in subgroup $1 \mathrm{a}(\mathrm{p}<0,01)$; however, between subgroups $2 \mathrm{~b}$ and $1 \mathrm{~b}$, a tendency for a lower rate of survival occurred in subgroup $2 b(p=0,06)$. No significant difference in the survival frequency between group STPI and the simulation group, whether submitted or not to HBO, was observed $(p>0,05)$. The frequency of survival of members of subgroup 3a, was significantly higher than that of members of subgroup 2a $(p<0,05)$. No difference was shown when subgroup $3 b$ was compared with group $2 b(p>0,05)$. HBO did not interfere with the survival of the animals of group STPI and of the simulation group, but did contribute to increase the number of survivals in the auto-implanted group. Total and fraction levels of cholesterol in the simulation group, whether treated or not by hyperbaric oxygen, did not present significant alterations in post-operation (P.O.) day 11, relative to the pre-operation picture. In group 2(implanted), a significant increase in cholesterol $(p<0,01)$, and in the LDL fraction ( $p<0,01)$ were observed on the $11^{\text {th }}$ P.O day in animals not treated with hyperbaric oxygen. This did nor occur in the treated animals (Figure 2). The HDL fraction did not present a significant alteration in the post-operative period of animals submitted 
TABLE 1 - Post-operative survival of the different animal groups after 11 days.

\begin{tabular}{|c|c|c|c|c|c|c|}
\hline Groups & Treatment & Survivors & Obits & $\mathbf{p}$ & $\mathbf{p}^{*}$ & $\mathbf{p}^{* *}$ \\
\hline \multirow[t]{2}{*}{ Simulation } & No OHB & $10(100 \%)$ & $0(0 \%)$ & & & \\
\hline & With OHB & $10(100 \%)$ & $0(0 \%)$ & & & \\
\hline \multirow[t]{2}{*}{ Auto- implanted } & No OHB & $9(42,85 \%)$ & $12(57,15 \%)$ & 0,004 & & \\
\hline & With OHB & $10(66,66 \%)$ & $5(33,34 \%)$ & 0,06 & & 0,19 \\
\hline \multirow[t]{2}{*}{ STPI } & No OHB & $11(84,61 \%)$ & 2(15,39\%) & 0,48 & 0,03 & \\
\hline & With OHB & 7( 77,77\%) & $2(22,23 \%)$ & 0,21 & 0,66 & 1,00 \\
\hline
\end{tabular}

Simulation- spleen manipulation. Auto-implanted- spleen auto-implantation. STPIsubtotal splenectomy preserving the inferior pole. Chisquare test; Fisher's test was used when one of the expected frequencies was smaller than 5. p- Auto-implant and STPI without HBO in relation to stimulation without $\mathrm{HBO}$, and Auto-implant and STPI with HBO relative to simulation with HBO. $\mathrm{p}^{*}$ - STPI without HBO in

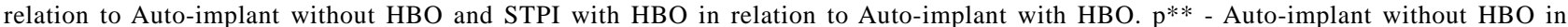
relation to Auto-implant with HBO, and STPI without HBO in relation to STPI with HBO.

or not to HBO. In group 3 (STPI), a significant increase of cholesterol $(p<0,01)$, of LDL fractions $(p<0,05)$, VLDL $(p<0,01)$, of triglicerides $(\mathrm{p}<0,01)$, was observed on the P.O. day 11 in animals not submitted to hyperbaric oxygentherapy. In the animals submitted to this treatment, no alteration of these lipids was observed in any of the three groups (Figure 2). IgG and IgA did not present significant alterations on the $11^{\text {th }}$ P.O day, in relation to the pre-operative condition, in any of the operated groups, not only in the HBO treated, but also in the nontreated animals. IgM was not altered in animals submitted to spleen manipulation, whether treated or not with $\mathrm{HBO}$, but was more significantly decreased on the $11^{\text {th }}$ P. O. day in animals of subgroups $2 \mathrm{a}, 2 \mathrm{~b}$ e $3 \mathrm{a}(\mathrm{p}<0,001)$, rather than in those of subgroup $3 \mathrm{~b}$ ( $\mathrm{p}<0,01$ ). Howell Jolly corpuscles were not observed pre operation in any of the animals. In the post-operation group 1(simulation), they were absent both in hyperbaric oxygen treated and non-treated animals. In group 2 (auto-implanted), 48 corpuscles were observed in nine animals not submitted to $\mathrm{HBO}$, and 25 in 10 treated animals (p $>0,05$ ). In group 3 (STPI), 32 corpuscles were observed in 11 non HBO treated rats and 10 corpuscles in 7 treated ones ( $>0,05)$. The number of corpuscles in the implanted animals, treated or not by $\mathrm{HBO}$, relative to the number of corpuscles in the animals of the simulation group, whether treated or not, was significantly higher $(\mathrm{p}<0,05)$. The number of corpuscles of group STPI was percentwise, but not significantly smaller than of those of the implanted group, regardless of the utilization of HBO. Platelet levels in the simulation group whether or not HBO-treated, did not present significant alterations on the $11^{\text {th }}$ P.O day, in relation to the pre-operation period. Platelet increase was more significant in the implanted than in the STPI group in animals submitted ( $p<0,001$ vs $p<0,01$ ) or not submitted ( $p<0,001$ vs $p<0,01)$ to HBO. The macroscopic aspect of the spleen of the simulation group did not present alterations. The organ showed few adherences to the abdominal wall or adjacent víscera. This aspect was similar in the animals post-operatively treated or not with HBO. The auto-implants presented adherences to the intestinal loops. Necrosis with secretion was shown in three auto-implants in one rat. In the other cases, the grafts presented a normal aspect. In the group of animals submitted to HBO, two cases of necrosis of auto-implants were observed in one rat. In the other cases, the aspect of the grafts was normal with a better macroscopic appearance of the group submitted to HBO that also presented adherences. The macroscopic appearance of the inferior poles did not differ between groups exposed or not to HBO. The adherences were present in all case, sometimes to the stomach, others to the intestinal loops and other still to the abdominal wall. The microscopic aspect (Figure 3) of the spleen of animals of the simulation group, whether or not treated with $\mathrm{HBO}$, was similar. Hemossiderosis, extramedullary hematopoiesis and presence of hemophagocytosis at the red pulp were observed. These are aspects compatible with those found in normal spleen. In the group submitted to auto-implants without $\mathrm{HBO}$, sub-total coagulant necrosis, intense perisplenic fibrosis, centripetal macrophagic infiltration and areas of acinar atrophy pancreas, were observed. In the group auto-implanted, treated with $\mathrm{HBO}$, the same alterations but with a lesser area of necrosis, were observed. The residual perisplenic tissue was better preserved, with the possible presence of neo-formed vessels. In animals of the STPI group submitted or not to HBO, fibrous perisplenitis, and coagulant necrosis of the red pulp, besides hemophagocytosis, were observed.

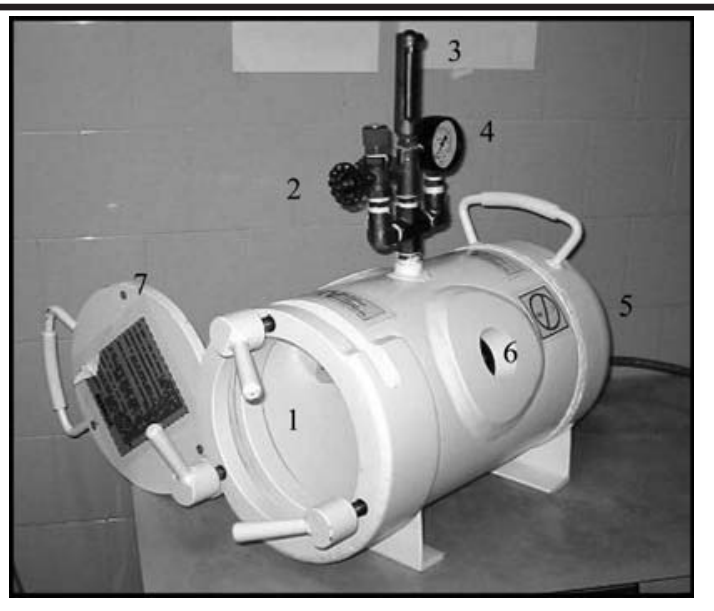

FIGURE 1 - Hyperbaric chamber of cylindrical capsule shape built from carbon steel. 1- Entrance and outlet of the chamber; 2- Oxygen escape valve; 3Thermometer; 4- Manometer; 5- Tube for oxygen entrance into the chamber; 6- Viewer for the observation of animals within the chamber; 7- Chamber occlusion lid. The chamber is $27 \mathrm{~cm}$ wide, $25 \mathrm{~cm}$ long and 1,5 cm thick. 


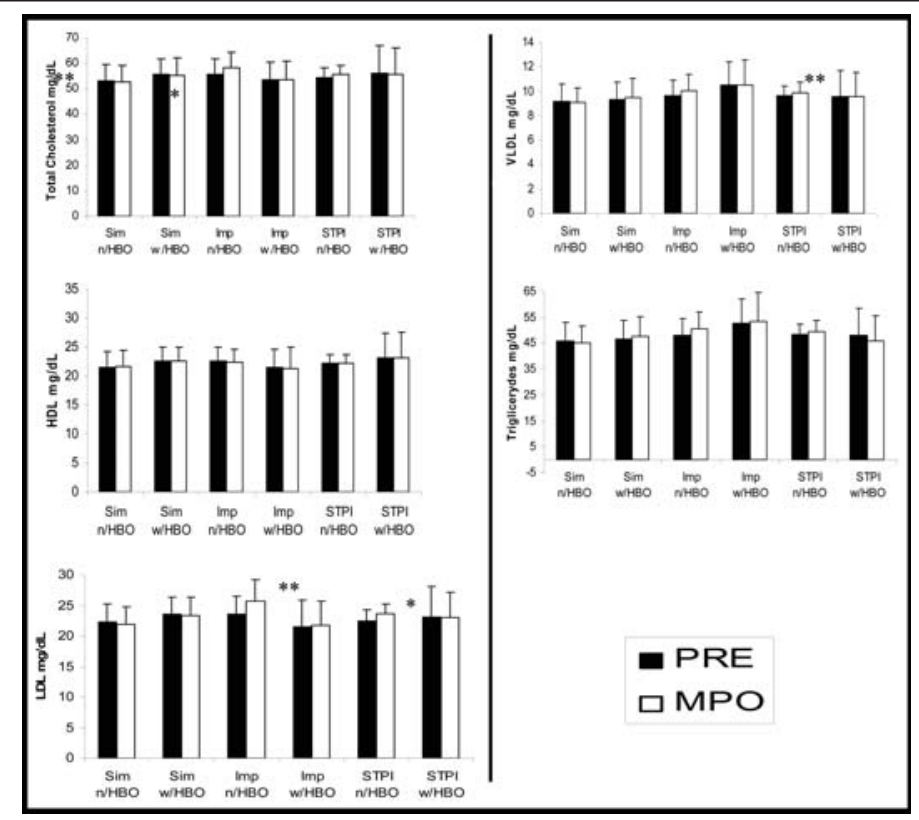

FIGURE 2 - Plasma lipid levels in animals submitted to spleen manipulation (Sim); to spleen implant (Imp) and to subtotal splenectomy with preservation of the inferior pole (STPI), not treated (n/HBO) and treated with hyperbaric oxygen therapy (w/HBO). Columns represent arithmetic means and bars above the columns, the standard deviations. PRE-pre-operation. MPO- mediate postoperation (11th post- operation day). ${ }^{*}$ - $\mathrm{p}<0,05$ relative to pre-operation; ** - $\mathrm{p}<0,01$ relative to pre-operation

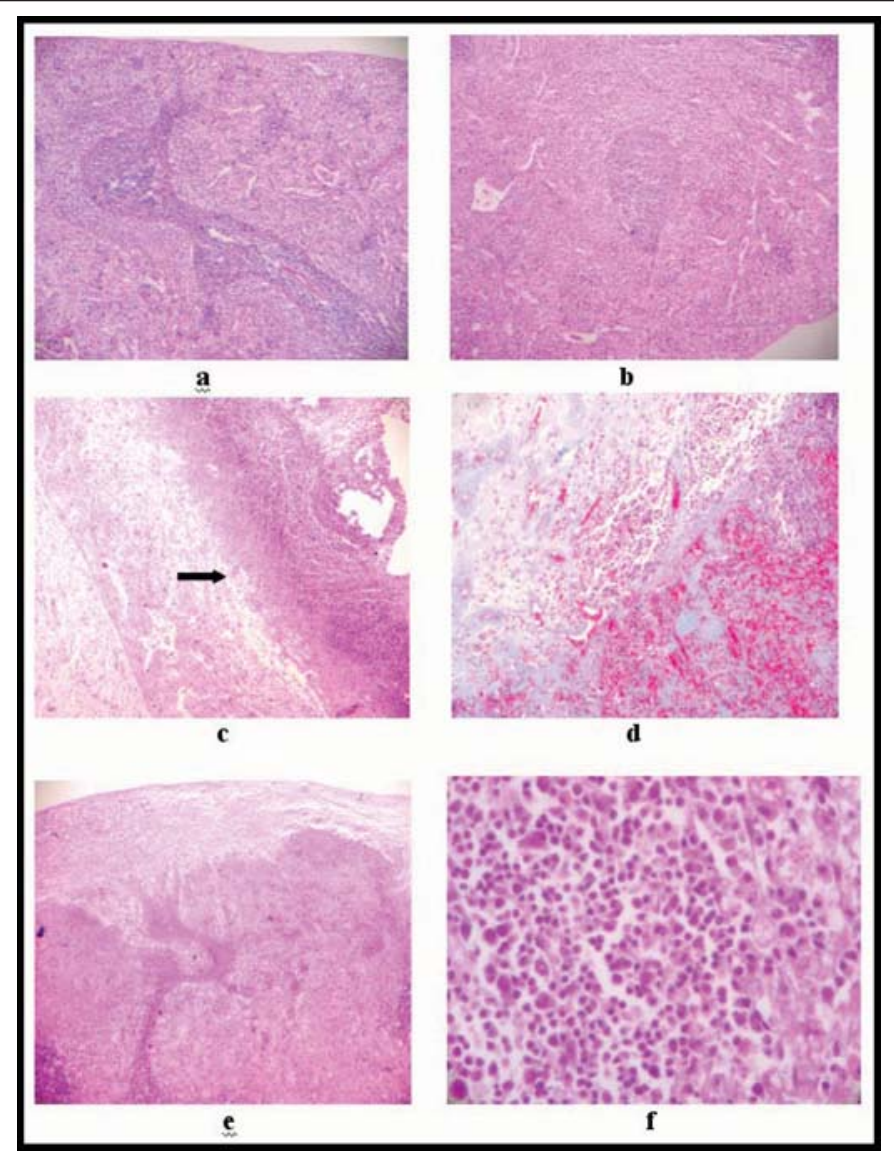

FIGURE 3 - Micropscopic aspects: a) Simulation group, not submitted to HBO. The aspect resembles that of the normal spleen (40 $x$ HE magnification); b), Simulation group, submitted toHBO show similar aspect to the former (40 x HE magnification); c) Auto-implanted group, not submitted to HBO. Sub-total coagulant necrosis (arrow), intense periesplenic fibrosis, macrophage centrípetal infiltration and areas of acinar atrophy of the pancreas (40 x HE magnification); d) Autoimplant group with HBO showed fibrosis, but no areas of coagulant necrosis, a perisplenic more preserved tissue at 40 x HE magnification); e) STPI group, not submitted to HBO, showing extensive areas of coagulant necrosis (40 x HE magnification); f) STPI group submitted to HBO, showing a more preserved peri-arteriolar sheath and a higher lymphoid population (100 x, HE magnification). 


\section{Discussion}

When we compared the weight of the animals of the same group, in the pre-operative and post-operative condition respectively, we observed a significant or not decrease in the second condition, in all groups. This result is predictable because in the immediate postoperation stage, the systemic response to aggression causes weight loss on its own. Considering that the animals were of the same gender and race and had been maintained in the same environment, undergoing the same treatment, and that prior to the operation no significant differences between the weights of the animals of the three groups were shown, we could in a certain way, set up the different comparisons between their periods of survival, as well as of functional and histological characteristics. When analyzing the frequency of survival of the animals in the three groups not submitted to HBO, we verified that in the simulation group, no deaths had occurred; and that the incidence of deaths in the implanted group was significantly higher in comparison with the simulation group $(p<0,01)$ or to the STPI group $(\mathrm{p}<0,05)$. The frequency of the implanted animals that survived, was higher in the HBO-treated group in comparison to the not so treated group, although this difference was not significant $(p>0,05)$. This demonstrates a certain protecting effect of the HBO in the group of implanted animals. In the STPI group, the HBO did not demonstrate a protective survival effect since no difference between the number of survivals of the oxygen-treated and untreated group was observed ( $p>0,05)$. Thus, the inferior pole protects, the animal more than the implant, and $\mathrm{HBO}$ contributes to this protection. In this work we could not define the causes of the deaths. Some of our microscopy findings however, suggest acute pancreatitis The literature records the possibility of deaths by different bacteria ${ }^{16}$ following splenectomy. More detailed studies on this issue deserve attention. Taking into consideration that HBO has a beneficial effect on acute pancreatitis ${ }^{25,26,27}$, stimulates collateral circulation ${ }^{24}$, has an angiogenic effect ${ }^{22,23}$, fights infection by various bacteria 28, 29,30, and increases hepatic regeneration ${ }^{31}$; it is admissible that this form of treatment decreases obit frequency. As a matter of fact, decreased rate of obits of rats submitted to hyperbaric oxygentherapy following hepatic veins ligature, has been reported ${ }^{32}$. If we confront the levels of total cholesterol and fractions, and of triglycerides in the simulation group, whether treated or not with hyperbaric oxygen in the mediate period, relative to the pre-operative condition, we note no significant differences. We can also observe that there were no alterations in IgM, Howell Jolly numbers of corpuscles, of platelets in the referred to post-operation periods, and groups exposed or not to hyperbaric oxygen. This shows that spleen maintenance of the simulation group is able to keep the referred laboratory parameters unaltered, regardless of whether the animals have or not been treated with HBO. Therefore, HBO did not interfere with spleen function. In the auto-implanted group, if we compare lipid levels in the pre-operation condition with those of the mediate post-operation period, in animals not submitted to a HBO, we observe a significant increase of total cholesterol and the LDL fraction. Considering the significant loss of IgM, increase of de Howell Jolly corpuscles and of platelets in this period, it must be admitted that the implants did not totally fulfill return of spleen function in contrast to that observed in the simulation group. This is a predicable result since literature reports show that implants only present efficient function after 16 weeks ${ }^{19}$. On the $11^{\text {th }}$ post-operation day, in animals of the auto-implanted group treated with $\mathrm{HBO}$, lipid levels remained unaltered, the fall of IgM was less significant than in the untreated implanted group, and the Howell Jolly corpuscles appeared in the circulation at a lower percentage in the treated group. This demonstrates that HBO contributed to improve implant function, possibly by accelerating the "take" of these grafts in this early period. Microscopic examination demonstrated greater preservation of spleen tissue in animals treated with $\mathrm{HBO}$. When comparing lipid levels in the STPI group not submitted to HBO in the postoperation vs. the pre-operation periods, we observed a significant increase of total cholesterol ( $p<0,01$ ), of the LDL fractions $(p<0,05)$, of the VLDL $(p<0,01)$ and of triglycerides $(\mathrm{p}<0,01)$, a significant drop of IgM ( $p$ $<0,001$ ) and the presence of Howell Jolly corpuscles (32 in 11 rats) and a significant increase of platelets $(\mathrm{p}<$ $0,001)$. These results lead us to admit that the functioning of the inferior spleen pole on the 11th P.O period. lipid metabolism, production of IgM, clearing of de Howell Jolly corpuscles and platelets, was still deficient. However, in this same group, submitted to $\mathrm{HBO}$, results were different, since lipid levels did not undergo significant variation relative to the pre-operation, IgM decreased in a less significant way, Howell Jolly corpuscles were detected in lower numbers in the circulation and platelets increased less significantly in relation to the group not given $\mathrm{HBO}$. Such results show that HBO improves inferior pole function as it did in the implants over the eleventh- day period. It is possible that this pole immediately following STPI, is not adequately supplied with blood. Ischaemia however, is the cause of adherences ${ }^{33}$, that may become vascularized. Upon removal, the inferior pole frequently presented adherences to the omentum or the abdominal wall; at these sites, we frequently observed vessels. It is possible that neo-formed vessels contribute to splenic regeneration, as already reported.$^{34}$ The inferior pole functions better after 90 days following STPI. ${ }^{8}$ Vascular neoformation in the inferior pole deserves further investigation. The inferior pole, although not having been 
as efficacious as the integral spleen, was better off than the auto-implants because: a- it permitted more survivals; b- evoked better platelet and Howell Jolly corpuscle clearing, and did not evoke such a marked falling of IgM ; c-The macro and microscopic appearance of the inferior pole presented itself more viable than that of the autoimplants. Hyperbaric oxygentherapy did not interfere with animals of the simulation group, but was beneficial to the auto-implanted and to the inferior pole carrying ones, because: a- Auto-implanted animals submitted to HBO survived in higher numbers than untreated ones; b- Such animals also presented a better function; cFurthermore, the aspect of their implants was better than that from untreated animals; $d$ - The inferior pole function was better in animals submitted to hyperbaric oxygentherapy. The analysis of our results showed that the survival of animals with a whole spleen or with its inferior pole, was more frequent than that of autoimplanted rats, and that the function and viability of the integral spleen or of its inferior pole were better than those in the auto-implants. Hyperbaric oxygentherapy contributed to increase the frequency and life survival of the auto-implanted rats, improving function and viability to levels similar to those possessing the inferior pole, and not interfering with the properties of animals carrying an integral spleen.

\section{References}

1. Resende LSR, Machado PEA. Complicações da Esplenectomia. In: Petroianu A.editors. O Baço. São Paulo: Baliero Editores Ltda, 2003. p. 302-6.

2. King H, Shumacker Jr HB. Splenic studies . Ann Surg. 1952; 136: 239-42.

3. Morris DH, Bullock FD. The importance of the spleen in resistance to infection. Ann Surg. 1919; 70: 513-21.

4. Andersson R, Alwmark A, Bengmark S. Outcome of pneumococcal challenge in rats after splenic artery ligation or splenectomy. Acta Chir Scand. 1986; 152: 15-7.

5. Aviram M, Brook JG, Tatarsky, Levy Y, Carter A. Increased low-density lipoprotein levels after splenectomy: a role for the spleen in cholesterol metabolism in myeloproliferative disorders. Am J Med Sci. 1986; 291: 25-8.

6. Asai K, Kuzuya M, Naito M, Funaki C, Kuzuya F. Effects of splenectomy on serum lipids and experimental atherosclerosis. Angiology. 1988 ; 39: 497-504.

7. Paulo DNS, Lázaro da Silva A. Lipídios plasmáticos após esplenectomia total e parcial em cães. Rev Col Bras Cir. 2001; 28: 264-70.

8. Petroianu A, Veloso DFM, Costa GR, Alberti LR. Efeitos de operações sobre o baço no lipidograma de ratas. Rev Assoc Med Bras. 2006; 52(1): 56-9.
9. Warshaw A L. Conservation of the spleen with distal pancreatectomy. Arch Surg. 1988; 123: 550-3.

10. Lin PW, Shan YS- Effects of splenectomy and splenic artery ligation on the portal presure in portal hypertensive rats. J Surg Res.1992; 53: 621-4.

11. Feliciano DV, Bitondo CG, Mattox KL, Rumisek JD, Burch JM, Jordan GL Jr .A four-year experience with splenectomy versus splenorrhaphy. Ann Surg. 1985; 201(5): 568-75.

12. Campos Cristo M. O estado da arte da cirurgia do baço, no início do século XXI.Rev Col Bras Cir 2005; 32(5): 279-82.

13. Petroianu A, Ferreira VLM, Barbosa AJA. Morphology and viability of the spleen after subtotal splenectomy. Braz J Med Biol Res. 1989; 22:491-5.

14. Paulo DNS, Paulo ICAL, Kalil M, Vargas PM, Lázaro da Silva A, Baptista JFA, Guerra AJ. Subtotal splenectomy preserving the lower pole in rats: technical, morphological and functional aspects. Acta Cir Bras. 2006; 21(5): 1-10.

15. Holdsworth RJ. Regeneration of the spleen and splenic autotransplantation. Brit J Surg. 1991; 78: 270-8.

16. Marques RG, Petroianu A, Coelho JMCO, Portela MC. Morfologia e função fagocitária de implante esplênico autógeno regenerado em ratos. Acta Cir Bras. 2004; 19(6): 1-11.

17. Jamel MJ, Refineti RA, Silva MM, Maciel ACC, Marelli GB. Papel do remanescente esplênico no perfil lipídico. Arq Bras Cir Dig. 2002; 15: 105-7.

18. Alves HJ, Viana G, Magalhães MM, Arantes RM, Coelho PM, Cunha-Melo JR. Kinects of neovascularization of splenic autotransplants in mice. J Anat. 1999; 195: 387-92.

19. Linuma H, Okinaga K, Sato S, Tomioka M, Matsumoto K. Optimal site and amount of splenic tissue for autotransplantation. J Surg Res. 1992; 53: 109-16.

20. Paulo ICAL, Paulo DNS, Lázaro da Silva A, Foletto RM, Colnago GL, Vargas PM. Níveis de lipides plasmáticos em ratos submetidos à esplenectomia total, ligadura simultânea dos vasos esplêncos e à esplenectomia subtotal com preservação do pólo inferior. Rev Col Bras Cir. 2005; 32(5): 229-36.

21. Zago MA. The evaluation of spleen function in man. Braz J Med Biol Res. 1989; 22: 159-69.

22. Muhonen A, Haaparanta M, Grönroos T, Bergman J, Knuuti J, Hinkka S, Happonen RP. Osteoblastic activity andRM neoangiogenesis in distracted bone of irradiated rabbit mandible with or without hyperbaric oxygen treatment. Int J Oral Maxillofac Surg. 2004; 33(2): 173-8.

23. Cundall JD, Gardiner A, Chin K, Laden G, Grout P, Duthie G. Hyperbaric oxygen in the treatment fecal incontinence secondary to pudendal neuropathy. Dis.Colon Rectum. 2003; 46(11): 1549-54.

24. Burt JT, Kapp JP, Smith RR. Hyperbaric oxygen and cerebral infarction in the gerbil. Surg Neurol. 1987; 28: 265-8. 
25. Mas N, Isik AT, Mas MR, Comert B, Tasci I, Deveci S, Ozyurt M, AtesY, Yamanel L, Doruk H, Yener N. Hyperbaric oxygen-induced changes in bacterial translocation and acinar ultrastructure in rat acute necrotizing pancreatitis. J Gastroenterol. 2005; 40(10): 980-6.

26. Yasar M, Yildiz S, Mas R, Dundar K, Yildirim A, Korkmaz A, Akay C,Kaymakcioglu N, Ozisik T, Sem D. The effect of hyperbaric oxygen treatment on oxidative stress in experimental acute necrotizing pancreatitis. Physiol Res. 2003; 52(1): 111-6.

27. Cheng HM, Shyr MH, Ueng SW, Chen MF. Hyperbaric oxygen therapy attenuates pancreatic microcirculatory derangement and lung edema in an acute experimental pancreatitis model in rats. Pâncreas. 1998; 17(1): 44-9.

28. Bedrikow R, Golin V. Oxigenoterapia Hiperbárica no Doente Cirúrgico. In: Rasslan S, editor. O Doente cirúrgico na UTI. Clínicas Brasileiras de Medicina Intensiva.-CBMI. São Paulo- Rio de Janeiro-Belo Horizonte 2001. P.493-502. Ano 6. vol 10.

29. Iazzetti PE, Nunes PHF, Amaral CRM, Bolzani N. Câmara hiperbárica Experimental- Projeto e Construção. Anais da 26a Reunião Anual da SBPC. São Paulo 1984.

30. Dahm P, Roland FH, Vaslef SN, Moon RE, Price DT, Georgiale GS, Vieweq J. Outcome analysis in patients with primary necrotizing fasciitis of the male genitalia. Urology. 2000; 56(1): 31-5.
31. Tolentino EC, Ferez O, Oliveira GR, Ramalho FS, Ramalho LNZ, Zucoloto S, Castro e Silva Jr O. Oxigenoterapia hiperbárica e regeneração hepatica. Acta Cir Bras. 2003; 18: $1-8$.

32. Costa-Val R, Nunes TA, Oliveira e Silva RC, De Puy e Souza TK.Huyperbaric oxygen therapy in rats submitted to hepatic veins ligation : mortality valuation and histological study of liver and spleen. Acta Cir Bras. 2006; 21(1): 1-19.

33. Ellis $H$. The aetiology of post-operative abdominal adhesions. An experimental study. Br J Surg. 1962; 50: 10-16.

34. Torres OJM, Macedo EL, Picciani ERG, Nunes PMS, Costa JVG, Carvalho AB, Lobato Jr PS. Histological study of splenic regeneration in rats underwent to subtotal splenectomy. Acta Cir Bras. 2000; 15(2): 1-12.

\section{Acknowledgments}

We thank the Departamento de Apoio à Pesquisa Clínica e Experimental do Instituto de Desenvolvimento Sustentável (Instituto Solidário do Espírito Santo) for financial support.

\section{Correspondence:}

Isabel Cristina Andreatta Lemos Paulo Rua Santa Rita de Cássia- Bairro de Lourdes 29042-753- Vitória, ES,Brasil

Phone: 0XX - 27-3222-1545

Fax: 0XX - 27-33234827

E-mail: icpaulo@unimedvitoria.com.br
Conflito de interesse: nenhum Fonte de financiamento: Departamento de Apoio à Pesquisa Clínica e Experimental do Instituto de Desenvolvimento Sustentável (Instituto Solidário do Espírito Santo) 